\title{
Retraction: microRNA-155 Modulates Hepatic Stellate Cell Proliferation, Apoptosis, and Cell Cycle Progression in Rats With Alcoholic Hepatitis via the MAPK Signaling Pathway Through Targeting SOCS1
}

\author{
Frontiers Editorial Office* \\ Frontiers Media SA, Lausanne, Switzerland
}

Keywords: microRNA-155, suppressor of cytokine signaling 1, mitogen activated protein kinase signaling pathway, alcoholic hepatitis, hepatic stellate cell, proliferation and apoptosis 3

Approved by:

Angelo A. Izzo,

University of Naples Federico II, Italy

${ }^{*}$ Correspondence:

Frontiers Editorial Office editorial.office@frontiersin.org

Specialty section: This article was submitted to Gastrointestinal and Hepatic

Pharmacology,

a section of the journal

Frontiers in Pharmacology

Received: 20 December 2021 Accepted: 20 December 2021 Published: 17 January 2022

Citation:

Frontiers Editorial Office (2022) Retraction: microRNA-155 Modulates Hepatic Stellate Cell Proliferation, Apoptosis, and Cell Cycle Progression in Rats With Alcoholic Hepatitis via the MAPK Signaling Pathway Through

Targeting SOCS1.

Front. Pharmacol. 12:840009.

doi: 10.3389/fphar.2021.840009

\section{A Retraction of the Original Research Article}

microRNA-155 Modulates Hepatic Stellate Cell Proliferation, Apoptosis, and Cell Cycle Progression in Rats With Alcoholic Hepatitis via the MAPK Signaling Pathway Through Targeting SOCS1

by Liu, D., Han, P., Gao, C., Gao, W., Yao, X., and Liu, S. (2020). Front. Pharmacol. 11:270. doi:10. 3389/fphar.2020.00270

The journal and Chief Editors retract the April 7, 2020 article cited above.

Following publication, concerns were raised regarding the validity of the data in the article. The authors failed to provide the raw data or a satisfactory explanation during the investigation, which was conducted in accordance with Frontiers' policies. Given the concerns, and the lack of raw data, the editors no longer have confidence in the findings presented in the article.

This retraction was approved by the Chief Editors of Frontiers in Pharmacology and the Chief Executive Editor of Frontiers. The authors have not responded to any correspondence regarding the retraction.

Copyright $(2022$ Frontiers Editorial Office. This is an open-access article distributed under the terms of the Creative Commons Attribution License (CC BY). The use, distribution or reproduction in other forums is permitted, provided the original author(s) and the copyright owner(s) are credited and that the original publication in this journal is cited, in accordance with accepted academic practice. No use, distribution or reproduction is permitted which does not comply with these terms. 